\title{
Methods for measuring venous peripherally inserted central catheters in newborns
}

\author{
Métodos de mensuração dos cateteres venosos centrais de inserção periférica em recém-nascidos \\ Métodos de medición de catéteres venosos centrales de inserción periférica en recién nacidos
}

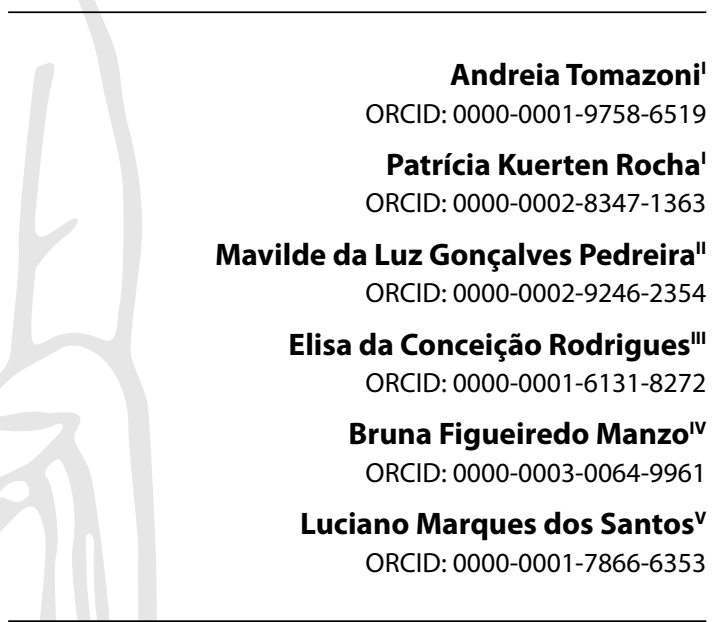

'Universidade Federal de Santa Catarina. Florianópolis, Santa Catarina, Brazil.

"Universidade Federal de São Paulo. São Paulo,

São Paulo, Brazil.

I'Universidade Federal do Rio de Janeiro. Rio de Janeiro, Rio de Janeiro, Brazil.

"Universidade Federal de Minas Gerais. Belo Horizonte, Minas Gerais, Brazil.

v Universidade Estadual de Feira de Santana. Feira de Santana,

Bahia, Brazil.

How to cite this article: Tomazoni A, Rocha PK, Pedreira MLG, Rodrigues EC, Manzo BF, Santos LM. Methods for measuring venous peripherally inserted central catheters in newborns.

Rev Bras Enferm. 2022;75(2):e20210045

https://doi.org/10.1590/0034-7167-2021-0045

\section{Corresponding author:}

Andreia Tomazoni

E-mail: andreiatomazoni@gmail.com

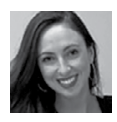

EDITOR IN CHIEF: Antonio José de Almeida Filho ASSOCIATE EDITOR: Fátima Helena Espírito Santo

\begin{abstract}
Objective: to analyze the results of insertion procedures of Peripherally Inserted Central Catheters in newborns using two measurement methods. Methods: this is a randomized clinical trial, presenting descriptive and exploratory results of variables. It was held at a Neonatal Intensive Care Unit. Data were collected between September 2018 and 2019. The sample analyzed was 88 catheter insertion procedures, distributed in two groups. Study approved by an Institutional Review Board and obtained registration in the country and abroad. Descriptive analysis and logistic regression of data. Results: modified measurement obtained a significant difference for the central catheter tip location. Elective removals and adverse events were not significant between groups; however, poor positioning was related to adverse events. Conclusions: between the two methods analyzed, the modified measurement obtained better results in the proper catheter tip positioning and, consequently, less risk to patients. Descriptors: Vascular Access Devices; Central Venous Catheters; Infant, Newborn; Intensive Care Units, Neonatal; Neonatal Nursing.
\end{abstract}

\section{RESUMO}

Objetivo: analisar os resultados dos procedimentos de inserção de Cateter Central de Inserção Periférica em recém-nascidos utilizando dois métodos de mensuração. Métodos: ensaio clínico randomizado, apresentando os resultados descritivos e exploratórios das variáveis. Realizado em Unidade de Terapia Intensiva Neonatal. Dados foram coletados entre setembro de 2018 e 2019. A amostra analisada foi de 88 procedimentos de inserção do cateter, distribuídos em dois grupos. Estudo aprovado no Comitê de Ética. Obteve-se registro no país e exterior. Análise descritiva e regressão logística dos dados. Resultados: o método de medida modificada obteve diferença significativa para a localização central da ponta do cateter. Retiradas eletivas e eventos adversos não foram significativos entre os grupos, porém o mau posicionamento foi relacionado com os eventos adversos. Conclusões: entre os dois métodos analisados, a medida modificada obteve melhores resultados no posicionamento adequado da ponta do cateter e, consequentemente, menores riscos aos pacientes. Descritores: Dispositivos de Acesso Vascular; Cateteres Venosos Centrais; Recém-Nascido; Unidades de Terapia Intensiva Neonatal; Enfermagem Neonatal.

\section{RESUMEN}

Objetivo: analizar los resultados de los procedimientos de inserción del catéter central de inserción periférica en recién nacidos mediante dos métodos de medición. Métodos: ensayo clínico aleatorizado, presentando los resultados descriptivos y exploratorios de las variables. Realizado en la Unidad de Cuidados Intensivos Neonatales. Los datos fueron recolectados entre septiembre de 2018 y 2019. La muestra analizada fueron 88 procedimientos de inserción de catéter, divididos en dos grupos. Estudio aprobado por el Comité de Ética. Se obtuvo el registro en el país y en el exterior. Análisis descriptivo y regresión logística de los datos. Resultados: el método de medición modificado obtuvo una diferencia significativa para la ubicación central de la punta del catéter. Los retiros electivos y los eventos adversos no fueron significativos entre los grupos; sin embargo, la mala posición se relacionó con los eventos adversos. Conclusiones: entre los dos métodos analizados, la medida modificada obtuvo mejores resultados en el correcto posicionamiento de la punta del catéter $y$, en consecuencia, menor riesgo para los pacientes.

Descriptores: Dispositivos de Acceso Vascular; Catéteres Venosos Centrales; Recién Nacido; Unidades de Cuidado Intensivo Neonatal; Enfermería Neonatal. 


\section{INTRODUCTION}

In Neonatal Intensive Care Units (NICU), newborns may need complex assistance interventions to maintain and improve their clinical stability, including inserting intravenous devices that allow infusion therapies with drugs and therapeutic fluids ${ }^{(1-2)}$.

Among the various devices used for this purpose, Peripherally Inserted Central Catheter, known as PICC, has been widely used in neonatal intensive care. Such a device is characterized by being a catheter inserted in a peripheral vein with progression and location in vessels close to the heart, indicating central positioning. Furthermore, in the case of neonatal patients, PICC is configured as the first option of choice for access to the venous network because it is a safe and effective alternative, when compared to other available alternatives ${ }^{(3-4)}$.

Among the benefits of using PICC, we highlight prolonged use for the maintenance of intravenous therapy, since it is a medium and long-term catheter, reduction of the amount of peripheral punctures, reduction of pain, lower rates of bloodstream infection related to the central catheter and reduced need of venous dissection $^{(3)}$.

Literature indicates that the ideal location of the PICC tip is in the superior vena cava or at the cavo-atrial junction, as it reduces the risk of complications related to this device. To assist in locating the PICC tip in the vena cava, there are different technologies that help in detecting the positioning of the catheter during or after a procedure, such as the use of ultrasound, intracavitary electrocardiogram or specific devices for this purpose ${ }^{(5-7)}$; however, they require financial investment and educational support for operationalization and are not accessible to all hospital contexts.

In the absence of technologies, the traditional method used before the procedure to prevent PICC malposition is based on the venous network's anatomy through anatomical measurement of the venous pathway to the central region. This measurement corresponds to the catheter length that will be introduced into the venous network, in order to obtain the tip location in a central position ${ }^{(1)}$. However, the traditional measurement method presents variation in the catheter tip location for neonatal patients, representing a challenge for an ideal PICC positioning ${ }^{(3,8-9)}$. Since newborns have differences, when compared to adults, between the location of the venous network and the anatomical landmarks used to measure the catheter ${ }^{(10)}$, when estimating the measurement, there may be poor positioning of the tip.

It is noteworthy that monitoring the catheter tip positioning is an issue addressed in scientific literature, since the incidence of poor positioning is between $10 \%$ and $60 \%$. Poor positioning can lead to the development of serious adverse events, such as cardiac tamponade, pleural and pericardial effusion, infiltration, endothelial injury, among others, being a risk to patient safety ${ }^{(11-12)}$. Therefore, the traditional PICC measurement poses challenges regarding the catheter tip positioning, and studying new measures can reduce the risks to patients.

Furthermore, the production of knowledge about alternative methods for insertion procedures of this catheter through controlled studies is fundamental for the adoption and implementation of evidence-based practice ${ }^{(13)}$. Thus, this research seeks to answer whether there is a difference in the results of PICC insertion procedures by comparing the traditional measurement method and a modified measurement method.

\section{OBJECTIVE}

To analyze the results of insertion procedures of Peripherally Inserted Central Catheters in newborns using two measurement methods of catheter length.

\section{METHOD}

\section{Ethical aspects}

Ethical issues were considered following the rules and guidelines of the Brazilian National Health Council (Conselho Nacional de Saúde) of the Ministry of Health, which regulate research involving human beings, according to Resolution 466 of December 12, 2012. The project was submitted to an Institutional Review Board through Plataforma Brasil and was approved by Universidade Federal de Santa Catarina and Hospital de Clínicas of Universidade Federal do Paraná.

\section{Study design, period, and location}

This is a quantitative study, with the design of a randomized clinical trial. It should be noted that this article presents the descriptive and exploratory results of the variables studied in a doctoral thesis entitled "Método de Medida do Cateter Central de Inserção Periférica em Recém-Nascidos: Estudo Randômico". To develop the study, the Consolidated Standards of Reporting Trial (CONSORT) guidelines was followed, which addresses the information and details necessary for conducting the study ${ }^{(14)}$. The study was registered at the Brazilian Clinical Trials Registry, under number RBR-3ky9sp and Universal Trial Number:U1111-1234-3718.

The study was carried out between March 2016 and February 2020 and data collection occurred from September 2018 to September 2019. The place of performance was at a Neonatal Intensive Care Unit of a public hospital in southern Brazil.

\section{Sample}

The sample consisted of the number of PICC insertion procedures performed on newborns admitted to a NICU, with newborns being those up to 28 days of life. The sample was calculated based on PICC insertion procedures and the study outcome, considering the success rate in the initial positioning of $50 \%$, confidence level of $95 \%$, statistical power of $80 \%$ and difference between the groups of $25 \%$, the minimum representative sample size being 110 PICC insertion procedures.

To be part of the sample, the procedures for inserting PICC in upper limbs performed on newborns were considered as inclusion criteria. PICC insertion procedures are considered in patients with non-viable venous network in the upper limbs for PICC insertion, PICC insertion procedures in newborns with congenital anomalies that present an abnormality in the venous network or displacement of the position anatomy of the heart, $\mathrm{PICC}$ insertion procedures in patients with diaphragmatic hernia were considered as exclusion criteria. 
During the collection period, 197 PICC insertion procedures were performed, 42 of which were not included in the research due to the exclusion criteria. Thus, 155 PICC insertion procedures were included and randomized. Of these, 67 were not completed due to puncture failure or failure to puncture the upper limbs. Thus, 88 procedures were included in data analysis (Figure 1).

The procedures for inserting PICC in the sample were divided into two groups (experimental and control) randomly allocated by randomization in chunks. The randomization process was carried out using the Microsoft Excel ${ }^{\circ}$ program, with chunks of random numbers of two (2), four (4) and six (6), in which PICC insertion procedures were randomly allocated to experimental and control groups.

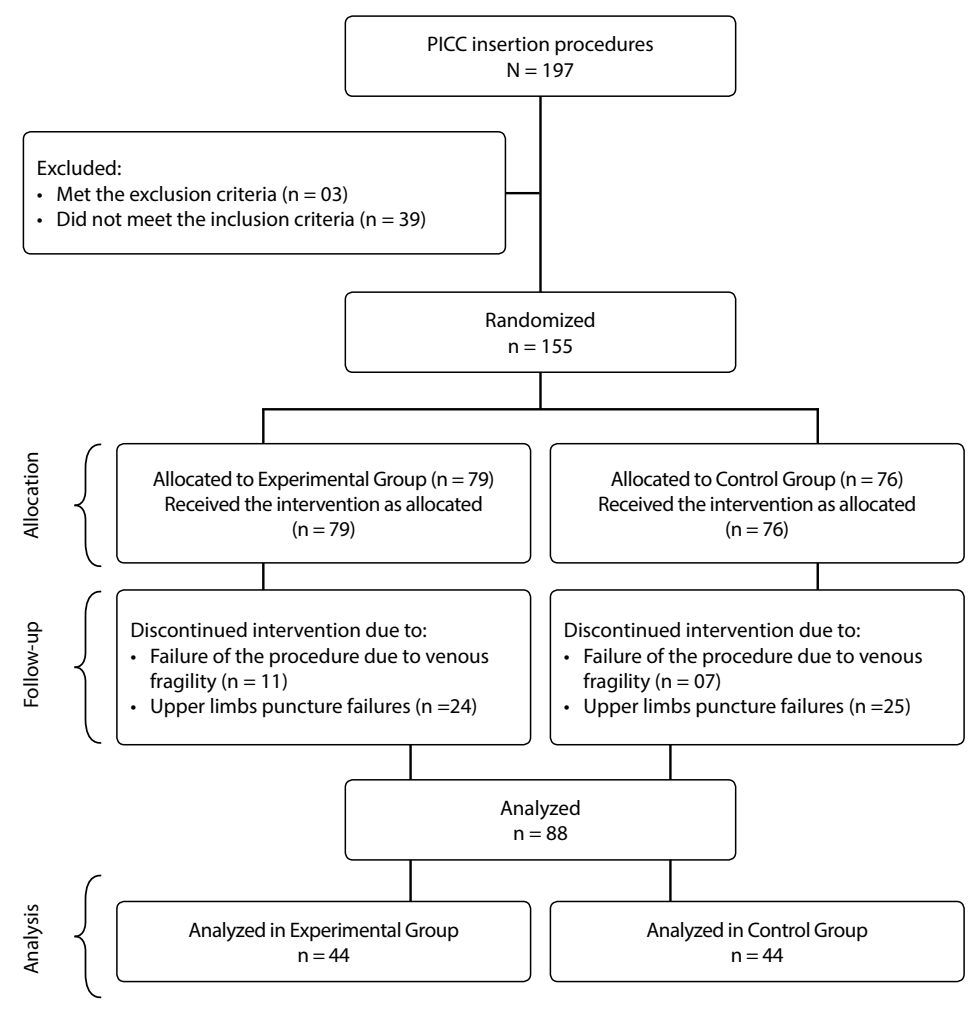

Source: Prepared based on CONSORT ${ }^{(14)}$.

Figure 1 - Flow diagram of the study steps, according to CONSORT Guidelines, Curitiba, Paraná, Brazil, 2020

\section{Study protocol and data collection}

Data collection followed a research protocol with the application of two PICC measurement methods. In the Control Group, the traditional measurement was applied: measurement of distance from puncture site to the right sternoclavicular space, adding the path to the third intercostal space ${ }^{(1)}$. In the Experimental Group, the modified measurement was applied: measurement of distance from puncture site to the right sternoclavicular space.

The 12 nurses who performed the procedures and agreed to participate in the research applied the catheter measurement techniques and filled out a research form for data collection. To this end, training was carried out through simulation of the data collection process, demonstrating the two PICC measurement methods. Nurses were trained step by step, from a clinical scenario similar to real work environment, containing materials used in the PICC procedure, a doll used to simulate the PICC measurement and data collection form. After training, a pilot test was carried out with 12 randomized PICC insertion procedures according to the itnerventions to be tested.

The actions taken by nurses during data collection were: verification of eligibility of PICC insertion following the inclusion and exclusion criteria; ICF application to those responsible for patients; verification of the randomization list, including patients' name and hospital registration number in the numerical sequence of the list; procedure allocation envelope opening according to the corresponding number on the randomization list; intervention application according to the allocation of the group indicated in a research protocol; completion of the procedure and recording of data in the data collection instrument.

The data collection instrument contained the following variables: a) Independent variable: PICC measurement methods for newborns; b) Dependent variable: initial location of the catheter tip (in the first location attempt); c) Variables for characterization of newborns: sex, gestational age at birth, corrected gestational age, birth weight, current weight, punctured limb, length of hospital stay; d) Variables for characterizing the procedure: catheter brand, catheter insertion site, catheter traction after radiography, traction length, catheter gauge, catheter insertion site, total catheter progression number of puncture attempts, inadequate catheter progression or curling, catheter traction after radiography, traction length, catheter tip location after traction, final location of PICC tip, PICC duration, reason for withdrawing PICC, occurrence of adverse event.

To verify the study outcome, chest radiographs were analyzed and "Initial location" was considered as PICC tip initial position after the procedure. Catheter tip with position in the superior vena cava or cavoatrial junction was categorized as "Central" position;"Peripheral", when catheter tip was located anterior to the vena cava (right axillary, left axillary, left jugular, right jugular, right subclavian, left subclavian, brachiocephalic); "Intracardiac", when catheter tip was below the cavo-atrial junction, i.e., inside the cardiac chamber (right atrium, ventricle) ${ }^{(1)}$.

\section{Analysis of results, and statistics}

The collected data were organized and tabulated in Microsoft Excel $^{\circ}$ spreadsheets. In the analysis, the study sample was initially characterized by obtaining absolute and relative frequencies of newborn characterization and procedure categorization variables. Then bivariate analysis was performed, estimating Relative Risk (RR) and its respective Confidence Intervals $(\mathrm{Cl})$ for length of stay and occurrence of adverse events. Initial location and final location of the PICC tip were considered to be dependent; the measurement method used was considered as an independent variable. Levels of statistical significance were assessed using Pearson's chi-square and Fisher's exact tests, with a significance level of $5 \%$.

In order to carry out the Logistic Regression analysis, the "Occurrence of adverse events" was considered as a dependent variable, classified as "Yes or No". The independent variables were 
"Group" (experimental or control) and "Final PICC tip location" (Central or Peripheral). "Central" classification was adopted as a reference category, being classified as "Final Location" the PICC tip position after repositioning interventions by means of traction. Program R version 3.6.1 was used to carry out the analyzes.

\section{RESULTS}

The results express data referring to 88 procedures for inserting PICC in the upper limbs, 44 from Control Group (CG) and 44 from Experimental Group (EG). Considering the 88 procedures that were part of data analysis, it was observed that indications for inserting PICC were the need for administration of total parenteral nutrition $(n=51 ; 58.0 \%)$, antibiotic therapy $(n=25 ; 28,4 \%)$ and vasoactive drugs $(n=12 ; 13.6 \%)$. PICCs used were polyurethane with a single lumen $(n=88 ; 100 \%)$, all of which were VYGON ${ }^{\circ}$. Among the catheter gauges used, the use of 2.0 French gauge $(n=80$; $90.9 \%)$ prevailed, followed by the 1.9 French gauge $(n=8 ; 9.1 \%)$.

It is noteworthy that, in order to obtain venous access, the puncture technique was performed by direct visualization of the vein, without the use of technologies for guided puncture, as such technologies are non-existent in the research unit. Thus, the results showed that $33(37.5 \%)$ procedures were successful in the first attempt of venipuncture; in $27(30.7 \%)$ procedures, there were between two (2) and three (3) attempts; in 21 (23.9\%), there were between four (4) and five (5) attempts. Moreover, in seven (7) $(8.0 \%)$ procedures, there were more than five (5) puncture attempts.

PICC insertion duration time for most patients was less than five (5) days ( $n=60 ; 68.2 \%)$, followed by six (6) to 10 days of hospitalization ( $n=16 ; 18.2 \%)$.

Analysis of gender, gestational age at birth, corrected gestational age, birth weight, current weight, and punctured limb did not represent a statistically significant difference when compared to each other (Table 1).

Immediately after the procedures performed, a chest X-ray was performed on the 88 (100\%) PICCs studied to confirm the catheter tip location. It was observed that partial progression of catheter length to the vena cava occurred in $10(11.4 \%)$ procedures, corresponding to four $(n=4 ; 9.1 \%)$ of the EG and six $(n=6 ; 13.6 \%)$ of the CG. Additionally, there was inadequate catheter progression in 19 procedures, eight $(n=8 ; 18.2 \%)$ of the EG and $11(25 \%)$ of the CG. It was found that an inadequate progression occurred due to the false path of PICC, causing the catheter to roll with progression to collateral vessels adjacent to central circulation (subclavian, jugular and axillary veins), being related to the outcome of peripheral position.

As for the initial location of PICC tip, the EG had a higher occurrence of central positioning, while the CG had a higher occurrence of intracardiac and peripheral positioning, this difference being statistically significant between the groups (Table 2).

In detail, it was observed that, in the EG, 21 (47.7\%) PICC had their tip in a central position, with the location in the superior vena cava in $17(38.6 \%)$ procedures, and in the cavoatrial junction, in four ( $n=4 ; 9.1 \%) .15$ (34.0\%) PICC were found in an intracardiac position. Furthermore, in a portion of the PICC inserted in the $E G$, the tip was in a peripheral position $(n=8 ; 18.2 \%)$, one in a subclavian vein $(n=1 ; 2.3 \%)$, four in jugular veins $(n=4 ; 9.1 \%)$ and three in axillary veins $(n=3 ; 6.8 \%)$.
Table 1 - Characterization of newborns from the Experimental Group and Control Group, submitted to Peripherally Inserted Central Catheter insertion in a Neonatal Intensive Care Unit in southern Brazil, Curitiba, Paraná, Brazil, 2020

\begin{tabular}{|c|c|c|c|c|c|}
\hline \multirow[t]{2}{*}{ Variables } & \multicolumn{2}{|c|}{$\begin{array}{c}\text { Experimental } \\
\text { group } \\
(\mathrm{N}=44)\end{array}$} & \multicolumn{2}{|c|}{$\begin{array}{c}\text { Control } \\
\text { group } \\
(\mathrm{N}=44)\end{array}$} & \multirow[t]{2}{*}{$\underset{\text { value }}{p}$} \\
\hline & $\mathbf{n}$ & $\%$ & $\mathbf{n}$ & $\%$ & \\
\hline \multicolumn{6}{|l|}{ Sex } \\
\hline Female & 23 & 52.3 & 16 & 36.4 & 0.198 \\
\hline Male & 21 & 47.7 & 28 & 63.6 & - \\
\hline \multicolumn{6}{|c|}{ Gestational age of birth } \\
\hline$<28$ weeks & 14 & 31.8 & 6 & 13.6 & 0.196 \\
\hline 28 to 31 weeks & 5 & 11.4 & 12 & 27.3 & 0.490 \\
\hline 32 to 33 weeks & 7 & 15.9 & 5 & 11.4 & 0.719 \\
\hline 34 to 36 weeks & 8 & 18.2 & 9 & 20.5 & 0.822 \\
\hline 37 to 42 weeks & 10 & 22.7 & 12 & 27.3 & - \\
\hline \multicolumn{6}{|c|}{ Corrected gestational age } \\
\hline$<28$ weeks & 9 & 20.5 & 6 & 13.6 & 0.368 \\
\hline 28 to 31 weeks & 8 & 18.2 & 11 & 25.0 & 0.865 \\
\hline 32 to 33 weeks & 5 & 11.4 & 6 & 13.6 & 0.951 \\
\hline 34 to 36 weeks & 12 & 27.3 & 6 & 13.6 & 0.156 \\
\hline 37 to 42 weeks & 10 & 22.7 & 15 & 34.1 & - \\
\hline \multicolumn{6}{|l|}{ Birth weight } \\
\hline$<1,000 \mathrm{~g}$ & 13 & 29.5 & 8 & 18.2 & 0.790 \\
\hline $1,000-1,499 g$ & 8 & 18.2 & 13 & 29.5 & 0.437 \\
\hline $1,500-2,499 g$ & 11 & 25.0 & 10 & 22.7 & 0.876 \\
\hline $2,500 \mathrm{a}$ to $2,999 \mathrm{~g}$ & 6 & 13.6 & 7 & 15.9 & 0.735 \\
\hline $3,000 \mathrm{~g}$ to $3,499 \mathrm{~g}$ & 2 & 4.5 & 4 & 9.1 & 0.563 \\
\hline$>3,500 \mathrm{~g}$ & 4 & 9.1 & 2 & 4.5 & - \\
\hline \multicolumn{6}{|l|}{ Current weight } \\
\hline$<1,000 \mathrm{~g}$ & 9 & 20.5 & 7 & 15.9 & 0.656 \\
\hline $1,000-1,499 g$ & 11 & 25.0 & 14 & 31.8 & 0.775 \\
\hline $1,500-2,499 g$ & 13 & 29.5 & 9 & 20.5 & 0.459 \\
\hline$>2,500 \mathrm{~g}$ & 11 & 25.0 & 14 & 31.8 & - \\
\hline \multicolumn{6}{|l|}{ Punctured member } \\
\hline Upper right limb & 18 & 40.9 & 26 & 59.1 & 0.667 \\
\hline Upper left limb & 21 & 47.7 & 23 & 52.3 & - \\
\hline
\end{tabular}

In the CG, it was found that PICC obtained an initial central location in one procedure $(n=1 ; 2.3 \%)$, with the tip positioned in the superior vena cava. It was observed that a considerable portion of the PICC was located in the intracardiac region, with $32(72.7 \%)$ catheters, $24(54.5 \%)$ in the right atrium and eight $(\mathrm{n}=8 ; 18.2 \%)$ in the ventricle. PICC tip location in the peripheral region was verified in 11 (25\%) procedures, five of which were in subclavian veins $(n=5 ; 11.4 \%)$, two in jugular veins $(n=2 ; 4,5 \%)$, four in axillary veins $(n=4 ; 9.1 \%)$.

It is noteworthy that all PICCs that were peripherally located, for both groups, had partial progression in catheter length or curling due to a false path; therefore, they were not related to the measurement methods used in each group.

Regarding catheter duration, it was found that in the EG there was a longer residence time when compared to the CG, however, it did not represent a statistically significant difference (Table 3).

As for the reasons for withdrawing the PICC, removal was performed for an elective reason at the end of treatment or for a non-elective reason due to occurrence of adverse events. In the $E G$, there were 27 (61.4\%) elective removals, while in the CG, there were 20 (45.5\%) elective removals.

The indications for non-elective removal were due to occurrence of adverse events such as catheter rupture, accidental traction, obstruction, infiltration, phlebitis, suspicion of infection 
or death. It was found that in the EG there was a higher frequency of obstruction $(n=3 ; 6.8 \%)$ and infiltration $(n=3 ; 6.8 \%)$. While in the $\mathrm{CG}$, the most prevalent reasons for non-elective removal were infiltration $(n=6 ; 13.6 \%)$, obstruction $(n=4 ; 9.1 \%)$, and phlebitis $(n=3 ; 6.8 \%)$.

It was found that, in the EG, the indication for removal due to adverse events occurred more frequently in the CG when compared to the EG. However, analysis showed that there was no statistically significant difference between the groups regarding occurrence of adverse events (Table 4).

Although the occurrence of adverse events was not related to the type of group, it is considered that there may be a higher occurrence of adverse events related to catheter tip location. For this, a logistic regression was performed to analyze the final location of PICC tip and occurrence of adverse events (Table 5).

It was found that the final location of PICC tip is related to occurrence of adverse events, with Odds Ratio being 3.25 times higher for the CG. For PICC procedures whose final tip location was in a bad position, Odds Ratio was 4.10 times higher than occurrence of adverse events, compared to procedures whose final location was in the central region.

\section{DISCUSSION}

Newborns may be in need of long-term therapies, with PICC being used mainly for hydration with electrolytes, carbohydrates, proteins and lipids, antibiotics and vasoactive drugs that require continuous and safe infusion ${ }^{(2)}$. PICC allows infusion of a variety of drugs safely, such as those that cannot be infused into peripheral veins due to the risk of endothelial injury and complications ${ }^{(15)}$; therefore, proper location of the catheter tip is fundamental for correct use of the device, and the study of measurement methods makes it possible to discuss better results in obtaining the correct positioning for newborns.

It is noteworthy that, during the follow-up of the study sample, 18 procedures were not completed due to the failure to obtain venous access, reflecting one of the difficulties for the success of intravenous therapy in newborns. It should be noted that venipuncture was performed using the visualization and direct puncture technique, with a small portion of the procedures being successful in the first venipuncture. Corroborating the results, a study in a Brazilian NICU demonstrated that success in the first puncture also represents limitations, obtaining an average of 3.7

Table 2 - Initial location of Peripherally Inserted Central Catheter tip in the Experimental Group and Control Group in a Neonatal Intensive Care Unit in southern Brazil, Curitiba, Paraná, Brazil, 2020

\begin{tabular}{lccccc}
\hline Group & \multicolumn{2}{c}{$\begin{array}{c}\text { Initial location of Peripherally Inserted Central Catheter tip } \\
\text { Central }\end{array}$} & Peripheral & Intracardiac & Total \\
\hline Experimental Group & 21 & 8 & 15 & 44 & Fisher's exact test \\
Control Group & 1 & 11 & 32 & 44 & $p$ value \\
Total & 22 & 19 & 47 & 88 & \\
\hline
\end{tabular}

Table 3 - Peripherally Inserted Central Catheter duration in the Experimental Group and Control Group in a Neonatal Intensive Care Unit in southern Brazil, Curitiba, Paraná, Brazil, 2020

\begin{tabular}{|c|c|c|c|c|c|}
\hline Duration & $\begin{array}{c}\text { Experimental group } \\
n(\%)\end{array}$ & $\begin{array}{c}\text { Control group } \\
n(\%)\end{array}$ & $\mathbf{R R}$ & $95 \% \mathrm{Cl}$ & $p$ value* \\
\hline 1 to 5 days & 7 (15.9) & $14(31.8)$ & 1 & - & - \\
\hline 6 to 10 days & $18(40.9)$ & $15(34.1)$ & 1.63 & $0.83-3.23$ & 0.231 \\
\hline 11 to 15 days & $12(27.3)$ & $6(13.6)$ & 2 & $1.00-3.98$ & 0.079 \\
\hline$>16$ days & $7(15.9)$ & $9(20.5)$ & 1.31 & $0.58-2.98$ & 0.760 \\
\hline
\end{tabular}

Note: Pearson's chi-square test was used in the analysis.

Caption: RR-Relative Risk; Cl-Confidence Interval.

Table 4 - Peripherally Inserted Central Catheters removed due to adverse events in the Experimental Group and Control Group in a Neonatal Intensive Care Unit in southern Brazil. Curitiba, Paraná, Brazil, 2020

\begin{tabular}{lcccccccc}
\hline \multirow{2}{*}{ Occurrence of adverse event } & \multicolumn{2}{c}{$\begin{array}{c}\text { Experimental group } \\
\text { n }\end{array}$} & \multicolumn{2}{c}{ Control group } & \multicolumn{3}{c}{ Total } \\
$\mathbf{n}$ & 27 & 61.4 & 20 & 45.5 & 47 & 53.4 & Fisher's exact test \\
\hline No & 17 & 38.6 & 24 & 54.5 & 41 & 46.6 & $p$ value \\
Yes & 44 & 100 & 44 & 100 & 88 & 100 & & 0.1995 \\
Total & & & & &
\end{tabular}

Table 5 - Logistic regression model of the final location of Peripherally Inserted Central Catheter tip and occurrence of adverse events in the groups, Curitiba, Paraná, Brazil, 2020

\begin{tabular}{lcccccc}
\hline & Estimate & SD & z value & p value* & OR & 95\% Cl \\
\hline (Intercept) & -1.3977 & 0.5497 & -2.5425 & 0.0110 & & \\
Control Group & 1.1786 & 0.5944 & 1.9829 & 0.0474 & 3.25 & $1.01-10.42$ \\
Final location & 1.4113 & 0.5965 & 2.3657 & 0.0180 & 4.10 & $1.27-13.20$ \\
\hline
\end{tabular}

Caption: SD - Standard deviation; OR - Odds Ratio; $\mathrm{Cl}$ - Confidence Interval. 
punctures per procedure ${ }^{(16)}$. Likewise, another study in a Brazilian NICU showed an average of 3.1 punctures with each procedure ${ }^{(17)}$.

It is reiterated that, when the first puncture is unsuccessful, new attempts or new procedures for catheter insertion are necessary, generating inestimable costs of patient suffering, pain, tissue injuries, exposure to the risk of infection, greater need for analgesics and sedatives and greater investment in professional labor ${ }^{(18)}$.

In this regard, adherence to technologies can assist in obtaining venous access, such as the use of ultrasound to assess and locate the blood vessel. Ultrasound-guided puncture is among the recommendations for patients who have weakened or difficult to access venous networks, such as the neonatal population ${ }^{(19)}$. A research points out that the use of ultrasound in venous punctures contributes to the success of the puncture, reducing vascular trauma ${ }^{(20)}$. Although the use of technologies requires financial support, it is highlighted that they could impact the reduction of direct costs of inserting PICCs, in addition to reducing the risks and pain of patients, since it would decrease the number of unsuccessful procedures. Therefore, the feasibility for the adoption of technologies, mainly in public services, requires an in-depth study for investments in human resources and equipment, analyzing the cost-benefit for its implementation ${ }^{(18)}$.

Regarding patient profile, studies carried out in Brazilian NICUs show that patients who received insertion of PICC were mainly newborns, the majority of whom were premature and with low birth weight, corroborating the profile found in this research ${ }^{(2-3,16)}$.

Considering the sites for inserting PICC, this research considered developing a measure for the exclusive measurement of upper limbs; therefore, all procedures were performed in these places. It is noteworthy that the upper limbs are the first choice for insertion, since they represent less risk of complications. The basilic, cephalic and brachial veins are the most suitable for insertion, as they have a larger caliber, a smaller number of valves, a less tortuous path, in addition to being places that favor the stabilization of the catheter and are closer to the vena cava ${ }^{(2,19)}$. Studies carried out with newborns address that the prevalent places for insertion of PICC were in upper limbs ${ }^{(3,12,16)}$.

In this study, it was identified the difficulty in the progression of catheters in some insertion procedures, with partial progression of the length measured in $10(11.4 \%)$ procedures. A study carried out in a Brazilian NICU also reports complications during the procedure, such as difficulty in progressing the catheter ${ }^{(8)}$. The difficulty in progressing the catheters can occur due to venous valves, deviations from the venous anatomy or excessive bleeding. In view of these situations, maneuvers can be performed to facilitate the catheter passage, such as repositioning patients, catheter traction and a new attempt at progression, instillation of saline solution, superficial massages and maneuvers of the punctured limb(21).

Another NICU study demonstrated difficulty in progressing 63 (25.8\%) procedures, indicating a significant relationship with the initial positioning of the catheter tip. They refer to the difficulty of progression in $50 \%$ of PICC with a non-central starting position, and $22 \%$ of PICC with a central position ${ }^{(22)}$. Corroborating these results, in our study it was found that all catheters with difficulty in progression had peripheral position, due to deviation of the catheter path and curling.
Furthermore, it was found that the modified measurement method of PICC obtained a greater central location and less intracardiac location when compared to the results of the traditional method. For the group that used the traditional measure, the frequency of central positioning was $2.3 \%(n=1)$ and intracardiac $72.7 \%(n=32)$. A study carried out in a Brazilian NICU, with 108 newborns, showed $15.7 \%$ of central position and $56 \%$ of occurrence of intracardiac location $^{(8)}$. Another study with 137 newborns showed $60.6 \%$ of central location and $38 \%$ of intracardiac location ${ }^{(9)}$. International studies conducted in China and India have found that the initial poor positioning of PICC represents less frequency due to the use of technologies for positioning the catheter tip ${ }^{(23-24)}$.

Literature points out that catheter tip location may be related to the measurement techniques performed prior to the insertion procedures, especially in newborns, due to their anatomical differences ${ }^{(10,25)}$. Thus, there is a need for studies like this that address new measurement possibilities to promote an adequate positioning, without the need for repositioning interventions, thus reducing the risk of complications to newborns.

Regarding duration, in Brazilian studies carried out in a NICU, the average stay was 10.6 days and 12.6 days, respectively ${ }^{(8-9)}$.

The indication for removing PICC should happen ideally at the end of the treatment, i.e., in an elective way. However, during the course of infusional therapy, adverse event situations may occur in which it will be necessary to remove the catheter, indicating a non-elective removal. It was found, in the present study, that the catheters inserted using the modified measure presented $61.4 \%$ of elective removals, while the catheters using the traditional measure obtained $45.5 \%$ of elective removals. Studies show a percentage of elective removals between $40.7 \%$ and $56.2 \%(8-9,16,26)$.

Regarding non-elective removals due to adverse events, it was found in this study that there was no statistically significant difference between the two measurement methods, although the traditional method had a higher percentage of adverse events (54.5\%). Studies show a variation of non-elective removals due to adverse events between $39.6 \%$ and $48.8 \%^{(8-9,16,26)}$.

Among the reasons for non-elective removal cited in the literature, there is leakage of solutions, phlebitis, obstruction or occlusion, catheter-related bloodstream infection, infection of the insertion site, tip migration, accidental traction, cardiac tamponade, rupture catheter and thrombosis ${ }^{(2,8,25)}$.

Given the context of adverse events, it was found in the present study that the occurrence of adverse events was related to PICC tip location, with the traditional measurement method representing greater chances of developing adverse events, since they occurred greater chances of poor positioning. Corroborating, a study evaluated the association between PICC complications in relation to the tip of the catheter in newborns. It was observed that non-central PICC developed more complications in less time, which can lead to non-elective catheter removal. Complications occurred mainly with the tip location in the subclavian vein. Brachiocephalic vein catheters represented a frequency of complications comparable to the central position ${ }^{(27)}$.

Therefore, the application of interventions that promote the correct management of PICC through technical improvement, are the most appropriate measures to promote the elective removal of the catheters, preventing complication ${ }^{(28)}$. 


\section{Study limitations}

The limitation of this manuscript is the data analysis restricted to the sample of procedures that were concluded without complications. The lack of technologies that assist in venipuncture represented a limiting factor for the study, since the procedures that were not successful in puncturing the upper limbs and needed to be punctured in other body regions made it impossible to statistically analyze the position of the tip related to the measurement proposal.

Thus, it is recommended to expand the results with other studies and neonatal populations to make it possible to compare the data and provide a discussion of results with evidence based on expanded samples.

\section{Contributions to nursing}

Considering the difficulties of properly positioning the PICC tip in newborns in Brazil, where access to technologies that assist in real-time positioning is a limiting factor for the success of the procedure, this study brought the modified measurement method as easy-to-use alternative to optimize the proper catheter location, generating less risk to patients.

\section{CONCLUSIONS}

It was found that the use of the modified measurement method represented better results for the proper PICC tip positioning, when compared to the traditional measurement used in the unit. Thus, the new measurement method may represent an alternative to reduce inappropriate positioning and, consequently, reduce risks to patients.

Adverse events are mainly related to the poor positioning of the catheters, therefore, monitoring the tip is essential to prevent complications. Ensuring proper positioning of the catheter tip can be performed prior to the insertion procedure by measuring the PICC length properly. It is noteworthy that the new method of measuring PICCs demonstrated a higher occurrence of central positioning of the tip, therefore, less chance of complications and greater safety of patients using PICCs.

\section{REFERENCES}

1. Gorski L, Hadaway L, Hagle ME, McGoldrick M, Orr M, Doellman D. Infusion Therapy Standards of Practice. J Infus Nurs[Internet]. 2016 [cited 2021 Sep 9];39(1S):S1-1S59. Available from: https://source.yiboshi.com/20170417/1492425631944540325.pdf

2. Martins C, Oselame GB, Neves EB. Cateter central de inserção periférica: revisão sistemática. Rev Atenc Saude. 2016;14(47):99-107. https:// doi.org/10.13037/ras.vol14n47.3358

3. Nobre KSS, Cardoso MVLML, Teixeira JL, Lopes MMCO, Fontenele FC. Cateter central de inserção periférica e dissecção venosa em bebês: estudo descritivo. Online Braz J Nurs. 2016;15(2):215-25. https://doi.org/10.17665/1676-4285.20165420

4. Di Santo MK, Takemoto D, Nascimento RG, Nascimento AM, Siqueira É, Duarte CT, et al. Cateteres venosos centrais de inserção periférica: alternativa ou primeira escolha em acesso vascular?. J Vasc Bras. 2017;16(2):104-12. https://doi.org/10.1590/1677-5449.011516

5. Liu G, Hou W, Zhou C, Yin Y, Lu S, Duan C, et al. Meta-analysis of intracavitary electrocardiogram guidance for peripherally inserted central catheter placement. J Vasc Access. 2019;20(6):577-85. https://doi.org/10.1177/1129729819826028

6. Spencer TR, Pittiruti M. Rapid central vein assessment (RaCeVA): a systematic, standardized approach for ultrasound assessment before central venous catheterization. J Vasc Access. 2019;20(3):239-49. https://doi.org/10.1177/1129729818804718

7. Pittiruti M, Scoppettuolo G, Dolcetti L, Emoli A. Clinical use of sherlock-3CG for positioning peripherally inserted central catheters. J Vasc Access. 2019;20(4):356-61. https://doi.org/10.1177/1129729818805957

8. Prado NCC, Silva RAR, Costa RHS, Delgado MF. Non-elective removal of the peripherally inserted central catheter in the neonatal unit. Rev Eletronica Enferm. 2018;20:a13. https://doi.org/10.5216/ree.v20.45559

9. Rangel RJM, Castro DS, Amorim MHC, Zandonade E, Christoffel MM, Primo CC.. Practice of insertion, maintenance and removal of peripheral inserted central catheter in neonates. Rev Pesqui Cuid Fundam. 2019;11(n.es):278-84. https://doi.org/10.9789/2175-5361.2019.v11i2.278-284

10. Tarr GP, Pak N, Taghavi K, Iwan T, Dumble C, Davies-Payne D, et al. Defining the surface anatomy of the central venous system in children. Clin Anat. 2016;29(2):157-64. https://doi.org/10.1002/ca.22663

11. Blackwood BP, Farrow KN, Kim S, Hunter CJ. peripherally inserted central catheters complicated by vascular erosion in neonates. JPEN J Parenter Entereral Nutr. 2016;40(6):890-5. https://doi.org/10.1177/0148607115574000

12. Colacchio K, Deng Y, Northrup V, Bizzarro MJ. Complications associated with central and non-central venous catheters in a neonatal intensive care unit. J Perinatol. 2012;32(12):941-6. https://doi.org/10.1038/jp.2012.7

13. Perin G, Scarpa M-G. Defining central venous line position in children: tips for the tip. J Vasc Access. 2015;16(2):77-86. https://doi. org/10.5301/jva.5000285

14. Schulz KF, Altman DG, Moher D. CONSORT 2010 statement: updated guidelines for reporting parallel group randomised trials. J Clin Epidemiol. 2010;63(8):834-40. https://doi.org/10.1016/j.jclinepi.2010.02.005

15. Sharma PK, Singh K. Venous access in neonates: our experience. Int J Contemp Pediatrics. 2018;5(4):1571-5. https://doi.org/10.18203/23493291.ijcp20182567 
16. Borghesan NBA, Demitto MO, Fonseca LMM, Fernandes CAM, Costenaro RGS, Higarashi IH. Peripherally inserted central catheter: practics of nursing team in the neonatal intensive care. Rev Enferm UERJ. 2017;25:e28143. https://doi.org/10.12957/reuerj.2017.28143

17. Montes SF, Teixeira JBA, Barbosa MH, Barichello E. Aparición de complicaciones relacionadas con el uso del catéter venoso central de inserción periférica (PICC) en los recién nacidos. Enferm Glob. 2011;10(24):1-9. https://doi.org/10.4321/S1695-61412011000400001

18. Pires ABM, Lima AFC. Direct cost of peripheral catheterization by nurses. Rev Bras Enferm. 2019;72(1):88-94. https://doi. org/10.1590/0034-7167-2018-0250.

19. Moureau NL. Vessel health and preservation: the right approach for vascular access. Cham: Springer International Publishing; 2019. https:// doi.org/10.1007/978-3-030-03149-7

20. Oliveira AM, Danski MTR, Pedrolo E. Technological innovation for peripheral venipuncture: ultrasound training. Rev Bras Enferm. 2016;69(6):1052-8. https://doi.org/10.1590/0034-7167-2016-0125

21. Pettit J, Wyckoff MMW. Peripherally inserted central catheters peripherally inserted central catheters: guideline for practice. 2 nd ed. Glenview: National Association Neonatal Nurses; 2007.

22. Costa P, Vizzotto MPS, Olivia CL, Kimura AF. Insertion site and tip position of peripherally inserted central catheter in neonates. Rev Enferm UERJ[Internet]. 2013 [cited 2021 Sep 8];21(4):452-7. Available from: https://www.e-publicacoes.uerj.br/index.php/enfermagemuerj/article/ view/10001/8131

23. Oleti T, Sankar MJ, Thukral A, Sreenivas V, Gupta AK, Agarwal R, et al. Does ultrasound guidance for peripherally inserted central catheter (PICC) insertion reduce the incidence of tip malposition?: a randomized trial. J Perinatol. 2019;39(1):95-101. https://doi.org/10.1038/ s41372-018-0249-x

24. Zhou L, Xu H, Liang J, Xu M, Yu J. Effectiveness of intracavitary electrocardiogram guidance in peripherally inserted central catheter tip placement in neonates. J Perinat Neonatal Nurs. 2017;31(4):326-31. https://doi.org/10.1097/JPN.0000000000000264

25. Prabha L, Khan A, Galal M, Saba YE, Senthilkumar K. Central venous catheter-induced cardiac arrhythmias in neonates. In: Lakshmanadoss U, (Ed.). Cardiac arrhythmias. London: InTech Open; 2018. https://doi.org/10.5772/intechopen.74559

26. Silva VG, Pires ABM, Lima AFC. Cateter central de inserção periférica: motivos de remoção não eletiva e custo do consumo mensal. Cogitare Enferm. 2018;23(4):e57498. https://doi.org/10.5380/ce.v23i4.57498

27. Jain A, Deshpande P, Shah P. Peripherally inserted central catheter tip position and risk of associated complications in neonates. J Perinatol. 2013;33(4):307-12. https://doi.org/10.1038/jp.2012.112

28. Pedreira MLG. Obstrução de cateteres centrais de inserção periférica em neonatos: a prevenção é a melhor intervenção. Rev Paul Pediatr. 2015;33(3):255-7. https://doi.org/10.1016/j.rpped.2015.05.003 